\title{
Leaf anatomy of 'Marandu' grass cultivated in plant arrangements in agrosilvopastoral systems
}

\author{
Marcia Vitoria Santos ${ }^{(1)}$, Evander Alves Ferreira(1), Priscila Junia Rodrigues da Cruz ${ }^{(1)}$, \\ Victor Hugo Vidal Ribeiro(1), Brenda Thaís Barbalho Alencar ${ }^{(1)}$, Cássia Michelle Cabral(1), \\ Dayana Maria Teodoro Francino(1) and Ignácio Aspiazú(2)
}

\begin{abstract}
(1)Universidade Federal dos Vales do Jequitinhonhae Mucuri, Rodovia MGT-367, Km583, no5.000, Alto da Jacuba, CEP39100-000 Diamantina, MG, Brazil. E-mail: marciavitori@hotmail.com, evanderalves@gmail.com, cruzpjr@yahoo.com.br, victorhvribeiro@yahoo.com.br, barbalhobrenda@gmail.com, mtchells@yahoo.com.br, dayanafrancino@ufvjm.edu.br (2)Universidade Estadual de Montes Claros, Campus Janaúba, Rua Sertaneja, no 212, Vila Fátima, CEP 39440-000 Janaúba, MG, Brazil. E-mail: aspiazu@gmail.com
\end{abstract}

\begin{abstract}
The objective of this work was to evaluate the effects of different arrangements of eucalyptus plants on the morphoanatomical characteristics of leaf blades of 'Marandu' grass [(Urochloa brizantha (Syn. Brachiaria brizantha)] plants cultivated in agrosilvopastoral systems. The experiment was set in field conditions in a randomized complete block design with four replicates, in which the plots were represented by planting spacings of eucalyptus (12x2 and 12x4 m), and the subplots, by the distance between 'Marandu' grass and eucalyptus rows (6, 4, and $2 \mathrm{~m})$. A control was added, composed by 'Marandu' grass cultivated in full sun. Variables of the leaf anatomy of 'Marandu' grass were evaluated for shading interference by trees. The distance of 'Marandu' grass plants from the eucalyptus lines interfered with the leaf blade anatomy of the forage, and the highest modifications occurred in linear measures and tissue proportions in the arrangements with the highest eucalyptus density. The shading interference of eucalyptus on the anatomical characteristics of leaf blades of 'Marandu' grass depends on the adopted arrangement. This occurs due to the grass adaptation to the low-light incidence, with a consequent reduction in its physiological activity and growth.

Index terms: Urochloa brizantha, agroforestry systems, forest-livestock-crop integration, morphoanatomical characteristics.

\section{Anatomia foliar de capim-marandu cultivado em arranjos de plantio em sistemas agrossilvipastoris}

Resumo - O objetivo deste trabalho foi avaliar os efeitos de diferentes arranjos de plantas de eucalipto sobre as características morfoanatômicas de lâminas foliares de plantas de capim 'Marandu' [(Urochloa brizantha (Syn. Brachiaria brizantha)] cultivadas em sistemas agrossilvipastoris. O experimento foi estabelecido em condições de campo, em um delineamento de blocos ao acaso, com quatro repetições, em que as parcelas foram representadas pelos espaçamentos de plantio de eucalipto (12x2 e 12x4 m), e as subparcelas, pela distância entre o capim 'Marandu' e as fileiras de eucalipto (6, 4 e 2 m). Adicionou-se um controle apenas com capim 'Marandu', cultivado a sol pleno. As variáveis de anatomia foliar do capim 'Marandu' foram avaliadas quanto à interferência do sombreamento pelas árvores. A distância entre as plantas de capim 'Marandu' e as linhas de eucalipto interferiram na anatomia da lâmina foliar da forragem, e as maiores modificações ocorreram nas medidas lineares e proporções teciduais nos arranjos com maior densidade de eucalipto. A interferência do sombreamento pelo eucalipto nas características anatômicas das folhas de capim 'Marandu' depende do arranjo adotado. Isto ocorre em razão da adaptação do capim à baixa incidência de luz, com a consequente redução de sua atividade fisiológica e crescimento.

Termos para indexação: Urochloa brizantha, sistemas agroflorestais, integração lavoura-pecuária-floresta, características morfoanatômicas.

\section{Introduction}

The species Urochloa brizantha (Syn. Brachiaria brizantha) has a broad edaphoclimatic adaptation, and is easily spread due to the large amount of seed produced and their dormancy, which facilitates their dispersion over time and space. Its leaves are linear and numerous, usually densely hairy, especially the cultivar 'Marandu' (Gobbi et al., 2011), that is widely used in crop-livestock-forestry integrated systems, mainly in intercropping with corn and eucalyptus (Santos et al., 2015). 
One of the main obstacles in the management of agrosilvopastoral and silvipastoral systems is the alteration of the growth environment for the species that constitute the understory. The shade provided by the trees promotes significant changes in the microclimate, which may affect the morphology, anatomy, chemical, and bromatological composition of forage plants, which, in turn, may have effect on the growth, productivity, and quality of forage (Gobbi et al., 2011).

Among the main environmental factors affecting plant growth and development are the availability of light radiation, water, temperature, and nutrients (Akula \& Ravishankar, 2011). In forest environments, the wide variation of the availability of incident radiation is a limiting factor to the growth of seedlings and young individuals of certain species (Valladares \& Niinemets, 2008). The leaf is the primary photosynthetic organ that generally shows phenotypic plasticity in relation to light radiation, and its availability and quality can cause substantial effects on size and thickness and, thus, on the development of the organ (Valladares \& Niinemets, 2008; Sanches et al., 2009). When developing under full sun, leaves are generally thicker and have a greater photosynthetic capacity per unit area because of the increased amount of enzymes, and increased stomatal conductance in comparison to shaded leaves (Valladares \& Niinemets, 2008). However, the potential of acclimation to light is variable between species, as some of them may increase their photosynthetic capacity when transferred from low to high irradiance, or not, according to the anatomical plasticity (Taiz \& Zieger, 2013). Therefore, anatomical evaluation of plant responses to different shading levels are of great importance for the development of management systems to use agronomic, zootechnical, and arboreal species in multicrop systems, such as in agroforestry ones, also known as crop-livestock-forest. The lack of knowledge on the anatomical and micromorphological changes resulting from the exposure of forage species to different levels of shading, in agrosilvopastoral systems, motivated the development of this work.

The objective of this work was to evaluate the effects of different arrangements of eucalyptus trees on the anatomical characteristics of leaf blades of 'Marandu' grass plants intercropped with maize in agrosilvopastoral systems.

\section{Materials and Methods}

The experiment was carried out in an area with an agrosilvopastoral system established seven years before, with a clonal hybrid of Eucalyptus grandis x $E$. urophylla (Urograndis), clone 3336, and forage of the genus Urochloa (Syn. Brachiaria), in the Universidade Federal de Viçosa, in the state of Minas Gerais,

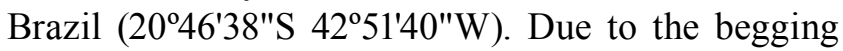
of pasture degradation, the area was renewed in November 2013, and corn (Zea mays L.) was cultivated in consortium with 'Marandu' grass. The soil of the experimental area is a Red Yellow Latosol (Oxisol), clayey with smooth and wavy relief, with the following chemical characteristics: $\mathrm{pH}$ in $\mathrm{H}_{2} \mathrm{O}, 5.60 ; \mathrm{P}, 1.13 \mathrm{mg}$ $\mathrm{dm}^{-3}$ (Mehlich-1); K, $41.00 \mathrm{mg} \mathrm{dm}^{-3} ; \mathrm{Ca}^{+2}, 3.33 ; \mathrm{Mg}^{+2}$, 0.57; $\mathrm{Al}^{+3}, 0.03 \mathrm{cmol}_{\mathrm{c}} \mathrm{dm}^{-3}\left(\mathrm{KCl} 1 \mathrm{~mol} \mathrm{~L}^{-1}\right)$; CTC (T), $5.99 \mathrm{cmol}_{\mathrm{c}} \mathrm{dm}^{-3}$; sum of bases, $2.34 \mathrm{cmol}_{\mathrm{c}} \mathrm{dm}^{-3} ; \mathrm{H}+\mathrm{Al}$, $3.65 \mathrm{cmol}_{\mathrm{c}} \mathrm{dm}^{-3} ; 2.37 \mathrm{dag} \mathrm{kg}^{-1}$ of organic matter; and $20.35 \mathrm{mg} \mathrm{dm}^{-3}$ of remaining P.

A completely randomized block experimental design was applied with four replicates. The treatments consisted of 'Marandu' grass, intercropped with corn and eucalyptus in an agrosilvopastoral systems, in split plots, in which the plots were represented by eucalyptus planting spacings $(12 \times 2$ and $12 \times 4 \mathrm{~m})$ and, the subplots, the distance between 'Marandu' grass and eucalyptus rows $(6,4$, and $2 \mathrm{~m})$. In addition, a control was added with 'Marandu' grass monoculture (grown in full sun). Corn was the double-cross BM207, with planiform leaves.

The experimental units were $12 \mathrm{~m}$ wide by 12 $\mathrm{m}$ long, covering $144 \mathrm{~m}^{2}$ area, consisting of two eucalyptus rows, interspersed with 'Marandu' grass and corn grown in the understory, in the intercropped plots. The monoculture plots were $12 \mathrm{~m}$ wide by $10 \mathrm{~m}$ long, covering $120 \mathrm{~m}^{2}$ area.

Desiccation was carried out in the experimental area, with $4 \mathrm{~L} \mathrm{ha}^{-1}$ glyphosate and $2.0 \mathrm{~L} \mathrm{ha}^{-1}$ 2,4-D, with $100 \mathrm{~L} \mathrm{ha}^{-1}$ spray volume, thirty days before the sowing of corn and 'Marandu' grass to form a mulch for the sowing with no-tillage.

The corn hybrid sowing was held in November, and cultivated between November 2013 and February 2014, by distributing 6 seed $\mathrm{m}^{-1}$, with $1.0 \mathrm{~m}$ row spacing, in $8 \mathrm{~m}$ in the center between rows of trees, in the intercropped plots. The fertilizer used in seeding was $400 \mathrm{~kg} \mathrm{ha}^{-1}$ of 8-28-16 $\left(\mathrm{N}-\mathrm{P}_{2} \mathrm{O}_{5}-\mathrm{K}_{2} \mathrm{O}\right)$ formulation. In the same time, the forage species was sown in and

Pesq. agropec. bras., Brasília, v.53, n.12, p.1320-1328, Dec. 2018 DOI: 10.1590/S0100-204X2018001200004 
between the corn rows, at $2 \mathrm{~cm}$ soil depth, using a multiple seeder (Semeato, model SHM 11/13). For all treatments, $4 \mathrm{~kg} \mathrm{ha}^{-1}$ viable pure seed of 'Marandu' grass were used. Nitrogen topdressing was applied 30 days after corn emergence at $100 \mathrm{~kg} \mathrm{ha}^{-1}$, using ammonium sulfate as source.

For the anatomical evaluations of 'Marandu', in February, four leaf blades were collected per subplot, two of which from a 'Marandu' plant cultivated within the corn row, and the other two ones from plants cultivated between corn rows. The youngest fully expanded leaf in the tiller was collected, with the total of 96 collected leaves.

The middle portion of the leaves was cut into segments of approximately $1 \mathrm{~cm}$ in length, which were fixed in FAA50 (formaldehyde:glacial acetic acid: ethanol, 5:5:90) for 48 hours (Johansen, 1940). Then, the samples were removed from the fixative solution, washed, and stored in ethanol solution at $70 \%$. For the preparation of the permanent slides, leaf portions were dehydrated in an ethanol series, and embedded in glycol methacrylate (Historesin, Leica Instruments, Heidelberg, Germany). Transverse leaf sections of $5 \mu \mathrm{m}$ thickness were obtained with the assistance of a manual rotary microtome (model 820, AO Scientific Instruments) and subsequently disposed upon histological slides, stained with toluidine blue (O'Brien et al., 1964), and assembled with Permount. Five slides were made for each sample unit.

Two scanned images were obtained from the material contained in each of the slides by averages of light microscopy Primo Star (Zeiss, Berlin, Germany), coupled with a digital camera Axio Cam ERc5s (Zeiss, Berlin, Germany).

Linear measures and area (tissue percentage) were determined using the software Image-Pro Plus 4.1. The following linear variables and tissue percentage were obtained: adaxial epidermis thickness (DET), abaxial epidermis thickness (BET), mesophyll thickness (MEST), leaf blade thickness (LBT); percentage of vascular bundle ( $\mathrm{VB} \%$ ), percentage of sheath cells of the vascular bundle (BSC\%), percentage of adaxial epidermis (ED\%), percentage of abaxial epidermis $(\mathrm{EB} \%)$, percentage of bulliform cells $(\mathrm{BLF} \%)$ and percentage of mesophyll cells (MES\%). To determine leaf blade thickness (LBT), five fragments fixed in FAA50 were included in 2-hydroxyethyl-methacrylate, sectioned at $7 \mu \mathrm{m}$, and stained with toluidine blue.

The characterization of the experimental units with eucalyptus trees during harvest is described on Table 1. The following information was determined: the number of trees per hectare as a function of spacing; the average values of tree heights; the breast height diameter $(\mathrm{cm}), 1.30$; and the estimation of wood volume $\left(\mathrm{m}^{3} \mathrm{ha}^{-1}\right)$ using the Schumacher \& Hall (1933) formula.

The wood volume per hectare was determined for the cultivated system (trees + crop + pasture), as well as the heights of corn and 'Marandu' grass plants. Concomitantly, the average shading exerted by trees on corn and 'Marandu' grass canopies was estimated 110 days after sowing, with the aid of a LI-COR device model LAI 20001, when corn plants were in the stage from dough to dent (corn silage point) by the time of the anatomical harvest. Readings were taken under diffuse light conditions (overcast weather, early morning, or late afternoon), following the recommendations for device use (Welles \& Norman, 1991). To determine the shading imposed by trees, the percentage of reduction of photosynthetically active radiation (PAR) was evaluated above the corn and 'Marandu' grass canopies, and compared to plants grown in full sun. The PAR measures were taken with

Table 1. Number of trees per arrangement, total height, breast height diameter (BHD), volume of wood per tree (Voltre), volume of wood per hectare of cultivated system (Volha), corn height, 'Marandu' grass (Urochloa brizantha) height, photosynthetically active radiation (PAR, $\mu \mathrm{mol} \mathrm{m}^{-2} \mathrm{~s}^{-1}$ ), and percentage of shade (\%) above corn and the 'Marandu' grass canopies and in full sun, at 110 days after sowing the species in an agrosilvopastoral system.

\begin{tabular}{|c|c|c|c|c|c|c|c|c|c|c|}
\hline Arrangement & $\begin{array}{l}\text { Number of } \\
\text { trees } \mathrm{ha}^{-1}\end{array}$ & $\begin{array}{l}\text { Height } \\
(\mathrm{m})\end{array}$ & $\begin{array}{l}\text { BHD } \\
(\mathrm{cm})\end{array}$ & $\begin{array}{l}\text { Voltre } \\
\left(\mathrm{m}^{3}\right)\end{array}$ & $\begin{array}{l}\text { Volha } \\
\left(\mathrm{m}^{3}\right)\end{array}$ & $\begin{array}{l}\text { Corn } \\
\text { height }\end{array}$ & $\begin{array}{l}\text { 'Marandu' } \\
\text { grass height }\end{array}$ & $\begin{array}{c}\text { Corn - PAR } \\
\text { and shade (\%) }\end{array}$ & $\begin{array}{l}\text { 'Marandu' } \\
\text { - PAR and } \\
\text { shade (\%) }\end{array}$ & $\begin{array}{c}\text { PAR of full } \\
\text { sun }(\mu \mathrm{mol} \\
\left.\mathrm{m}^{-2} \mathrm{~s}^{-1}\right)\end{array}$ \\
\hline $12 \times 2 \mathrm{~m}$ & 416 & 35.22 & 23.24 & 0.435 & 181.3 & 2.79 & 83.2 & $719.7-41.3$ & $512.5-58.2$ & 1226 \\
\hline $12 \times 4 \mathrm{~m}$ & 208 & 29.26 & 27.34 & 0.622 & 129.8 & 2.91 & 85.1 & $853.3-30.40$ & $388.6-68.3$ & 1226 \\
\hline
\end{tabular}


the equipment AccuPAR Linear PAR/LAI ceptometer, Model PAR-80 (Decagon Devices), according to recommendations for the equipment use.

Data were subjected to analysis of variance and, when significant, to the Tukey's test, at 5\% probability.

\section{Results and Discussion}

Corn plants grown in the $12 \times 4 \mathrm{~m}$ plots showed a higher exposure to radiation ( $30.4 \%$ shade) than those grown in the $12 \times 2 \mathrm{~m}$ plots ( $41.3 \%$ shade), which caused higher heights of corn plants (Table 1) and higher shade over 'Marandu' grass plants grown under the corn canopy (68.3 shade). These results corroborate those by Domingues et al. (2017), who found a higher corn production in less shaded areas.

When assessing adaxial epidermis thickness (DET), 'Marandu' grass plants, grown in the plots with eucalyptus in the $12 \times 4$ and $12 \times 2 \mathrm{~m}$ arrangements, showed no difference for the forage cultivation distances $(2,4$, and $6 \mathrm{~m})$ compared to the control (monocrop). However, when comparing the effect of the arrangements within each spacing of 'Marandu' grass to the eucalyptus rows, there was a reduction of the DET values in the higher density arrangement (12x2 $\mathrm{m}$ plot, in all distances of the tree crop) (Table 2). It is noteworthy that the DET ranged from $7.87 \mu \mathrm{m}$ (in the treatment in which 'Marandu' grass was grown $2 \mathrm{~m}$ of eucalyptus rows) to $9.32 \mu \mathrm{m}$ (in the distance of $2 \mathrm{~m}$ in the $12 \times 4 \mathrm{~m}$ arrangement), $15.56 \%$ thinner. Contrasting to these results, Baliza et al. (2012) found lower values of adaxial epidermis thickness (DET) in coffee plants grown in full sun, than under artificial shade of $35,50,65$, and $90 \%$.

Regarding thickness of the abaxial epidermis (BET) of 'Marandu' grass leaf blades, there was no difference between the forage cultivation distances and the control (full sun), in the plots where eucalyptus plants were grown in $12 \times 4$ and $12 \times 2 \mathrm{~m}$ arrangements. When evaluating the planting distances of the tree species, in different Eucalyptus arrangements, for 'Marandu' grass leaf anatomy, there was also no difference in BET. These results differ from what was found by Baliza et al. (2012). The thickness of abaxial epidermis (BET) was lower in coffee leaves cultivated in full sun than under $35 \%$ shading. The authors report that shade promotes distension of the epidermis cells by action of auxin, which results in thicker epidermis.
The thickness of the mesophyll (TMES) of 'Marandu' grass leaf blades collected at different distances from the eucalyptus row $(2,4$, and $6 \mathrm{~m})$ did not show differences in comparison to the control within the two eucalyptus planting arrangements $(12 \times 4$ and $12 \times 2 \mathrm{~m})$. However, for the effect of the arrangements within the distances of collection of 'Marandu' grass plants, it was found that at $6 \mathrm{~m}$ distance in the arrangement of $12 \times 4 \mathrm{~m}$ these plants showed higher TMES values than in the $12 \times 2 \mathrm{~m}$ arrangement. For the other distances, no changes

Table 2. Adaxial epidermis thickness (DET, $\mu \mathrm{m}$ ), abaxial epidermis thickness (BET, $\mu \mathrm{m})$, mesophyll thickness (MEST, $\mu \mathrm{m}$ ), leaf blade thickness (LBT, $\mu \mathrm{m}$ ) of 'Marandu' grass (Urochloa brizantha) cultivated 2, 4 and $6 \mathrm{~m}$ away from the eucalyptus rows ${ }^{(1)}$.

\begin{tabular}{|c|c|c|}
\hline \multirow{2}{*}{$\begin{array}{l}\text { Collection distance } \\
\text { of 'Marandu' grass } \\
\text { plants }\end{array}$} & \multicolumn{2}{|c|}{$\begin{array}{l}\text { Eucalyptus arrangement (spacing between plant } \\
\text { in the row) }\end{array}$} \\
\hline & $12 \times 4 \mathrm{~m}$ & $12 \times 2 \mathrm{~m}$ \\
\hline & \multicolumn{2}{|c|}{ Adaxial epidermis thickness (DET) } \\
\hline $2 \mathrm{~m}$ & $9.32 * \mathrm{Aa}$ & $7.87 \mathrm{Ab}$ \\
\hline $4 \mathrm{~m}$ & $9.66 \mathrm{Aa}$ & 8.96Aa \\
\hline $6 \mathrm{~m}$ & $9.89 \mathrm{Aa}$ & $8.28 \mathrm{Ab}$ \\
\hline Control & \multicolumn{2}{|c|}{$9.31 \mathrm{~A} / \mathrm{A}$} \\
\hline $\mathrm{CV}(\%)$ & \multicolumn{2}{|c|}{8.28} \\
\hline & \multicolumn{2}{|c|}{ Abaxial epidermis thickness (BET) } \\
\hline $2 \mathrm{~m}$ & $10.14 \mathrm{Aa}$ & 8.89Aa \\
\hline $4 \mathrm{~m}$ & $9.94 \mathrm{Aa}$ & $9.48 \mathrm{Aa}$ \\
\hline $6 \mathrm{~m}$ & $10.06 \mathrm{Aa}$ & $9.05 \mathrm{Aa}$ \\
\hline Control & \multicolumn{2}{|c|}{$9.60 \mathrm{~A} / \mathrm{A}$} \\
\hline CV $(\%)$ & \multicolumn{2}{|c|}{9.34} \\
\hline & \multicolumn{2}{|c|}{ Mesophyll thickness (MEST) } \\
\hline $2 \mathrm{~m}$ & $147.06 \mathrm{Aa}$ & $145.35 \mathrm{Aa}$ \\
\hline $4 \mathrm{~m}$ & $150.29 \mathrm{Aa}$ & $154.81 \mathrm{Aa}$ \\
\hline $6 \mathrm{~m}$ & $162.55 \mathrm{Aa}$ & $131.73 \mathrm{Ab}$ \\
\hline Control & \multicolumn{2}{|c|}{$155.90 \mathrm{~A} / \mathrm{A}$} \\
\hline $\mathrm{CV}(\%)$ & \multicolumn{2}{|c|}{16.49} \\
\hline & \multicolumn{2}{|c|}{ Leaf blade thickness (LBT) } \\
\hline $2 \mathrm{~m}$ & $169.71 \mathrm{Aa}$ & $149.66 \mathrm{Bb}$ \\
\hline $4 \mathrm{~m}$ & $176.00 \mathrm{Aa}$ & $137.18 \mathrm{Bb}$ \\
\hline $6 \mathrm{~m}$ & $158.96 \mathrm{Aa}$ & $152.32 \mathrm{Bb}$ \\
\hline Control & \multicolumn{2}{|c|}{$176.40 \mathrm{~A} / \mathrm{A}$} \\
\hline CV $(\%)$ & \multicolumn{2}{|c|}{5.97} \\
\hline
\end{tabular}

Pesq. agropec. bras., Brasília, v.53, n.12, p.1320-1328, Dec. 2018 DOI: $10.1590 /$ S0100-204X2018001200004 
were observed between arrangements (Table 2). Jiang et al. (2011) allocated sorghum (Sorghum bicolor) under four shade treatments (full sun, fully shaded, with young leaves shaded, and young leaves not shaded). The authors found different results from those found in the present study. Sorghum plants showed mesophyll thickness of adaxial and abaxial sides responses differentially to shading; while adaxial mesophyll thickness decreased about 16 to $23 \%$ in comparison to plants grown under full sun, mesophyll thickness in the abaxial side was less than $10 \%$ in either treatment (Jiang et al., 2011).

Leaf blade thickness (LBT) of 'Marandu' grass collected at different distances from the eucalyptus row, in the arrangement of $12 \times 2 \mathrm{~m}$, showed a variation in comparison to the control. The plots cultivated in full sun showed average LBT values of $176.40 \mu \mathrm{m}$, while the intercropped plants showed lower values. For the plants cultivated in the arrangement of $12 \times 4 \mathrm{~m}$, no difference was observed between treatments. During the passage of radiation through the leaf, it passes through successive layers of cells (Figures $1 \mathrm{~A}$ and
E), causing a decline in the intensity (Niinemets \& Sack, 2006). Jiang et al. (2011) noted that the shaded sorghum leaves were thinner, which is caused by the reduction in the palisade parenchyma of the leaves and could represent an attempt to increase diffusion of $\mathrm{CO}_{2}$ to the mesophyll (Gobbi et al., 2011).

As to the effect of the arrangements within the distances of collection of 'Marandu' grass, it was found that plants grown on plots where eucalyptus was planted in smaller spacing $(12 \times 2 \mathrm{~m})$ showed lower values of LBT in the collection distances of 2, 4, and $6 \mathrm{~m}$ (Table 2). In general, leaves that grow in shaded environments show a decrease of the mesophyll thickness and increased leaf blade area (Gomes et al., 2008; Gondim et al., 2008), to obtain a larger surface of absorption and optimize capturing photons. The decrease of leaf blade thickness of 'Marandu' grass cultivated in higher levels of shade $(12 \times 2 \mathrm{~m}, 58.2 \%)$ may have occurred due to a difference in the distribution of photoassimilates. Under the influence of a certain shading range, plants use a higher proportion of photoassimilates to increase leaf area in an attempt to maximize the uptake of
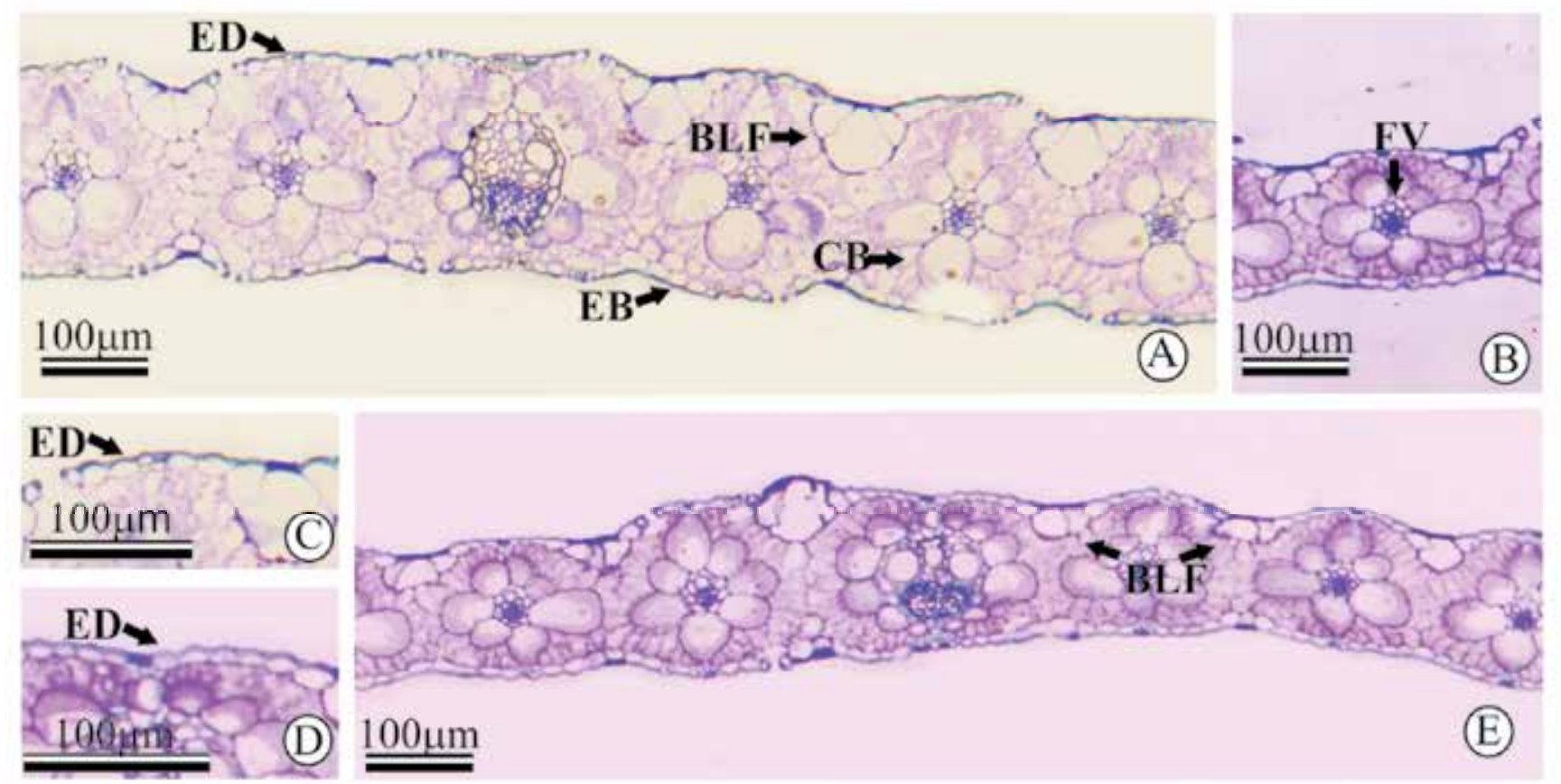

Figure 1. Cross section of leafblades of'Marandu' grass (Urochloa brizantha), in different arrangements in an agrosilvopastoral system: A, control in full sun; B, arrangement $12 \times 2 \mathrm{~m}$ at $2 \mathrm{~m} ; \mathrm{C}$, arrangement $12 \times 2 \mathrm{~m}$ at $6 \mathrm{~m} ; \mathrm{D}$, arrangement $12 \times 4 \mathrm{~m}$ at 6 $\mathrm{m}$; E, arrangement $12 \times 4 \mathrm{~m}$ at $2 \mathrm{~m}$. BLF, bulliform cell; FV, vascular bundle; CB, sheath cell; ED, adaxial epidermis; EB, abaxial epidermis. 
available light. They usually have thin leaves, higherspecific leaf area (SLA), and leaves with lower-mass density (Gobbi et al., 2011; Bosi et al., 2014).

Anatomical changes that occur in leaves developing under low-radiation conditions have an important role in the adaptation of the plant to the conditions imposed by the environment. Generally, these changes are related to increasing uptake and utilization of incident light, a resource that limits the growth in the shade, increasing the photosynthetic efficiency of the plant (Kirchner et al., 2010; Gobbi et al., 2011).

The percentage of vascular bundle (VB\%) did not differ between treatments and the control in the cross section of leaf blades of 'Marandu' grown in the understory of eucalyptus plants cultivated in the plot arrangement of $12 \times 4 \mathrm{~m}$. However, in the arrangement $12 \times 2 \mathrm{~m}$, at the distance of $2 \mathrm{~m}$ for collecting the forage, a decrease of $15.21 \%$ was observed in $\mathrm{VB} \%$ in comparison to the plots in full sun, with no significant difference from the other treatments. When comparing the values for the eucalyptus arrangements, within different distances of collection, there was only a difference between the arrangements in the 2 $\mathrm{m}$ distance of collection, whose values are 2.42 and $1.84 \%$, respectively, for the arrangements of $12 \times 4$ and $12 \times 2 \mathrm{~m}$ (Table 3 ).

Therefore, the shading provided a reduction of the proportion of vascular bundles. Similar results were observed by Gobbi et al. (2011), who described a decrease of the proportion of vascular and support tissues in Brachiaria, as well as reduction of thickness of cell wall as a function of shading. Assessing the anatomical responses of two temperate climate grasses for the reduction of light intensity, Wilkinson \& Beard (1975) found a lower proportion of vascular and support tissues in Poa pratensis plants subjected to shading.

Therefore, the smaller spacing of eucalyptus plants possibly promoted a decrease of fiber content because of a reduction in the proportion of vascular bundles (Figure $1 \mathrm{~B}$ ). Tissues like the sclerenchyma and the xylem, formed by thickened secondary cell wall, are the ones that contribute to the low quality of forages (Gobbi et al., 2011). These tissues form a solid multicellular block inside the rumen, which results in particles of large size that are poorly digested because of lignification and problems in the accessibility of rumen microorganisms to the surface of the cell wall (Gobbi et al., 2011). Some authors have found an
Table 3. Percentages of the vascular bundle, and of sheath cells of the vascular bundle, adaxial epidermis, abaxial epidermis, bulliform cells, and mesophyll cells of leaf blades of 'Marandu' grass (Urochloa brizantha) cultivated 2,4 , and $6 \mathrm{~m}$ away from the eucalyptus rows ${ }^{(1)}$.

\begin{tabular}{|c|c|c|}
\hline \multirow{2}{*}{$\begin{array}{l}\text { Distance of } \\
\text { 'Marandu' } \\
\text { grass plants }\end{array}$} & \multicolumn{2}{|c|}{$\begin{array}{c}\text { Eucalyptus arrangement } \\
\text { (spacing between plants in the row) }\end{array}$} \\
\hline & $12 \times 4 \mathrm{~m}$ & $12 \times 2 \mathrm{~m}$ \\
\hline & \multicolumn{2}{|c|}{ Percentage of vascular bundle (VB\%) } \\
\hline $2 \mathrm{~m}$ & $2.42 * \mathrm{Aa}$ & $1.84 \mathrm{Ab}$ \\
\hline $4 \mathrm{~m}$ & $2.17 \mathrm{Aa}$ & $2.07 \mathrm{Aa}$ \\
\hline $6 \mathrm{~m}$ & $2.73 \mathrm{Aa}$ & $2.00 \mathrm{Aa}$ \\
\hline Control & & \\
\hline \multirow[t]{2}{*}{$\mathrm{CV}(\%)$} & & \\
\hline & \multicolumn{2}{|c|}{ Percentage of sheath cells of the vascular bundle (BSC\% } \\
\hline $2 \mathrm{~m}$ & $4.58 \mathrm{Ab}$ & $3.37 \mathrm{Ba}$ \\
\hline $4 \mathrm{~m}$ & $4.62 \mathrm{Aa}$ & $5.25 \mathrm{ABa}$ \\
\hline $6 \mathrm{~m}$ & $5.08 \mathrm{Aa}$ & $5.92 \mathrm{Aa}$ \\
\hline Control & & \\
\hline \multirow[t]{2}{*}{$\mathrm{CV}(\%)$} & & \\
\hline & \multicolumn{2}{|c|}{ Percentage of adaxial epidermis (ED\%) } \\
\hline $2 \mathrm{~m}$ & $8.37 \mathrm{Ab}$ & $13.05 \mathrm{Aa}$ \\
\hline $4 \mathrm{~m}$ & $8.88 \mathrm{Aa}$ & $7.52 \mathrm{Ba}$ \\
\hline $6 \mathrm{~m}$ & $11.35 \mathrm{Aa}$ & $8.01 \mathrm{Ba}$ \\
\hline Control & & \\
\hline \multirow[t]{2}{*}{$\mathrm{CV}(\%)$} & & \\
\hline & \multicolumn{2}{|c|}{ Percentage of abaxial epidermis (EB\%) } \\
\hline $2 \mathrm{~m}$ & $8.76 \mathrm{Ab}$ & $14.01 \mathrm{Aa}$ \\
\hline $4 \mathrm{~m}$ & $9.68 \mathrm{Aa}$ & $8.72 \mathrm{Ba}$ \\
\hline $6 \mathrm{~m}$ & $10.34 \mathrm{Aa}$ & $8.60 \mathrm{Ba}$ \\
\hline Control & & \\
\hline \multirow[t]{2}{*}{ CV $(\%)$} & & \\
\hline & \multicolumn{2}{|c|}{ Percentage of bulliform cells (BLF\%) } \\
\hline $2 \mathrm{~m}$ & $1.55 \mathrm{Aa}$ & $2.35 \mathrm{Aa}$ \\
\hline $4 \mathrm{~m}$ & $1.46 \mathrm{Aa}$ & $1.60 \mathrm{Aa}$ \\
\hline $6 \mathrm{~m}$ & $1.75 \mathrm{Aa}$ & $1.52 \mathrm{Aa}$ \\
\hline Control & & \\
\hline \multirow[t]{2}{*}{$\mathrm{CV}(\%)$} & & \\
\hline & \multicolumn{2}{|c|}{ Percentage of mesophyll cells (MES\%) } \\
\hline $2 \mathrm{~m}$ & $74.32 \mathrm{Aa}$ & $57.37 \mathrm{Bb}$ \\
\hline $4 \mathrm{~m}$ & 73.18Aa & 74.81Aa \\
\hline $6 \mathrm{~m}$ & $68.74 \mathrm{Aa}$ & $74.93 \mathrm{Aa}$ \\
\hline Control & \multicolumn{2}{|c|}{$75.45 \mathrm{~A} / \mathrm{A}$} \\
\hline CV $(\%)$ & \multicolumn{2}{|c|}{14.58} \\
\hline
\end{tabular}

${ }^{(1)}$ Means followed by equal letters, uppercase in the columns and lowercase in the lines, do not differ by Tukey's test, at $5 \%$ probability.

Pesq. agropec. bras., Brasília, v.53, n.12, p.1320-1328, Dec. 2018 DOI: 10.1590/S0100-204X2018001200004 
increased digestibility of forage plants grown in the forest understory by reducing the fiber content (Barro et al., 2008; Lopes et al., 2017).

Regarding the percentage of vascular bundle sheath cells (BSC\%), no difference was verified between distances of forage collection in the plots where eucalyptus was grown in the arrangement of $12 \times 4 \mathrm{~m}$ (68.3\% shading). However, in the densest arrangement of tree species, 'Marandu' grass plants grown at $2 \mathrm{~m}$ from the eucalyptus rows showed lower-BSC $\%$ values than plants grown at $6 \mathrm{~m}$ from the trees and grown in full sun (Table 3). Contrasting with the present study, Gobbi et al. (2011) found a higher portion of BSC in signal grass leaves under intense shade (50\%), which might represent the need to increase photosynthetic efficiency under light restriction condition.

The sheath of the vascular bundle, a typical feature of $\mathrm{C}_{4}$ grasses, plays an important role in the process of those species photosynthesis because their cells contain the Rubisco enzyme, which - through the Calvin cycle - is responsible for refixation of the $\mathrm{CO}_{2}$ initially fixed by the PEP carboxylase enzyme in the mesophyll cells. This two-step process, which consists of C initial uptake in the mesophyll, and later photosynthetic $\mathrm{C}$ reduction in the vascular bundle sheath cells, is important for the inhibition of photorespiration, by concentrating $\mathrm{CO}_{2}$ at the site where the Rubisco enzyme operates (Majeran \& van Wijk, 2009; Jiang et al., 2011).

It is worth noting that these $\mathrm{BSC} \%$ values were 4.58 in the arrangement of $12 \times 4 \mathrm{~m}$ and 3.37 in the arrangement of $12 \times 2 \mathrm{~m}$ (differing from each other within the collection distance of $2 \mathrm{~m}$ from forage trees), and the value observed for the control was 4.82. Within the collection distances, there were no differences between the arrangements for the other treatments (Table 3). However, Deinum et al. (1996) found no significant variation in the proportion of vascular bundle sheath in Urochloa brizantha and Megathyrsus maximus leaves subjected to different levels of light intensity.

In the plots with eucalyptus in the arrangement of $12 \times 4 \mathrm{~m}$, 'Marandu' grass showed no differences for the percentage of adaxial epidermis (ED\%) between the different cultivation distances of the forage in the trees rows and the control. However, in the arrangement of $12 \times 2 \mathrm{~m}$, the cultivation distance of $2 \mathrm{~m}$ caused a higher value of $\mathrm{ED} \%$ than the other distances and the plants in full sun. As to the effect of arrangements within each distance of 'Marandu' grass from the trees, it was noted that the denser arrangement of the trees increased the average values of $\mathrm{ED} \%$ at $2 \mathrm{~m}$ of grass cultivation, and that value varied from $8.37 \%$ in the arrangement $12 \times 4$ $\mathrm{m}(30.4 \%$ shade) to $13.05 \%$ in the arrangement of $12 \times 2$ (41.3\% shade) respectively (Figures $1 \mathrm{C}$ and $\mathrm{D}$ ).

Similar results to those found for $\mathrm{ED} \%$ were observed for abaxial epidermis (EB\%). In the plots cultivated with 'Marandu' grass, in the $12 \times 4 \mathrm{~m}$ arrangement, there was no difference of EB\% for the different distances of the grass and the control. In the $12 \times 2 \mathrm{~m}$ arrangement, the 'Marandu' grass cultivated $2 \mathrm{~m}$ away from the eucalyptus rows showed higher-EB\% values (14.1\%). In the arrangement factor within the different distances of forage cultivation, only the $2 \mathrm{~m}$ distance showed a difference between the arrangements, and the values were $8.76 \%$ for the $12 \times 4 \mathrm{~m}$ arrangement and $14.01 \%$ for the $12 \times 2 \mathrm{~m}$ one (Table 3 ). Gobbi et al. (2011) evaluated the anatomical characteristics of $B$. decumbens 'Basilisk' and Arachis pintoi, and found no changes for $\mathrm{ED} \%$ and $\mathrm{EB} \%$ in plants grown at 50 and $70 \%$ levels of shade, in comparison to plants grown in full sun. Their results differ from those of the present study. Murphy et al. (2012) suggest that increasing values of epidermis percentage are proportionally related to leaf sizes, which are larger under intense shading conditions.

Bulliform cell percentages (BLF\%) did not change in the different cropping arrangements of tree species and growing distances from 'Marandu' grass in relation to the rows of the forage species (Table 3). This result may indicate that the leaf transpiration area in response to environmental conditions was not affected. The bulliform cells are bulky epidermal cells responsible for the curling of leaves (Alvarez et al., 2008).

When assessing the percentage of mesophyll (MES\%) of the leaf blades of 'Marandu' grass plants (Figures $1 \mathrm{~A}$ and $\mathrm{E}$ ), it was found that plants grown in plots where the trees were planted in the arrangement of $12 \times 4 \mathrm{~m}$ showed no difference between the evaluated distances and the control. However, in the arrangement of $12 \times 2 \mathrm{~m}$ with eucalyptus, 'Marandu' cultivated $2 \mathrm{~m}$ away from the eucalyptus rows showed a lower average value of $\mathrm{MES} \%$ than the other treatments. When evaluating the effect of eucalyptus arrangements within each distance of 'Marandu' grass cultivation, it was found that only the distance of $2 \mathrm{~m}$ showed a significant difference between the arrangements, and 
the average values for MES\% were 74.32 and $57.37 \%$ in the $12 \times 4$ and $12 \times 2 \mathrm{~m}$ arrangements, respectively (Table 3). This result is opposite to those of Gobbi et al. (2011), who found no changes for MES\% in $B$. decumbens 'Basilisk' and Arachis pintoi under shade and in full sun. The lower values of MES\% could be related to the lesser stress caused by high-light and heat under the tree canopy.

\section{Conclusions}

1. The shade imposed by the trees do not impact adaxial and abaxial epidermis thickness, mesophyll thickness, and percentage of bulliform cells in 'Marandu' grass [(Urochloa brizantha (syn. Brachiaria brizantha)].

2. Moderate shade provides the leaf blade thinness, reduces the proportion of mesophyll cells and the proportion of vascular bundles, and increases the percentage of epidermal tissues (abaxial and adaxial) in 'Marandu' grass.

\section{Acknowledgments}

To Coordenação de Aperfeiçoamento de Pessoal de Nível Superior (Capes), to Conselho Nacional de Desenvolvimento Científico e Tecnológico (CNPq), and to Fundação de Amparo à Pesquisa do Estado de Minas Gerais (Fapemig), for financial support.

\section{References}

AKULA, R.; RAVISHANKAR, G.A. Influence of abiotic stress signals on secondary metabolites in plants. Plant Signaling \& Behavior, v.6, p.1720-1731, 2011. DOI: 10.4161/psb.6.11.17613.

ALVAREZ, J.M.; ROCHA, J.F.; MACHADO, S.R. Bulliform cells in Loudetiopsis chrysothrix (Nees) Conert and Tristachya leiostachya Nees (Poaceae): structure in relation to function. Brazilian Archives of Biology and Technology, v.51, p.113-119, 2008. DOI: $10.1590 / \mathrm{S} 1516-89132008000100014$.

BALIZA, D.P.; CUNHA, R.L. da; CASTRO, E.M. de; BARBOSA, J.P.R.A.D.; PIRES, M.F.; GOMES, R.A. Trocas gasosas e características estruturais adaptativas de cafeeiros cultivados em diferentes níveis de radiação. Coffee Science, v.7, p.250-258, 2012.

BARRO, R.S.; SAIBRO, J.C.de; MEDEIROS, R.B. de; SILVA, J.L.S. da; VARELA, A.C. Rendimento de forragem e valor nutritivo de gramíneas anuais de estação fria submetidas a sombreamento por Pinus elliottii e ao sol pleno. Revista Brasileira de Zootecnia, v.37, p.1721-1727, 2008. DOI: 10.1590/ S1516-35982008001000002.
BOSI, C.; PEZZOPANE, J.R.M.; SENTELHAS, P.C.; SANTOS, P.M.; NICODEMO, M.L.F. Produtividade e características biométricas do capim-braquiária em sistema silvipastoril. Pesquisa Agropecuária Brasileira, v.49, p.449-456, 2014. DOI: 10.1590/S0100-204X2014000600006.

DEINUM, B.; SULASTRI, R.D.; ZEINAB, M.H.J.; MAASSEN, A. Effects of light intensity on growth, anatomy and forage quality of two tropical grasses (Brachiaria brizantha and Panicum maximum var. Trichoglume). Netherlands Journal of Agricultural Science, v.44, p.111-124, 1996

DOMINGUES, M.S.; ANDRIGHETTO, C.; LUPATINI, G.C.; MATEUS, G.P.; ARANHA, A.S.; ONO, R.K.; SHIGUEMATSU, M.M. dos S.; GIACOMINI, P.V.; SEKIYA, B.M.S. Growth and yield of corn forage intercropped with marandu grass in an agrosilvopastoral system with eucalyptus. Semina: Ciências Agrárias,v.38,p.3669-3680,2017.DOI: 10.5433/1679-0359.2017v3 8n6p3669.

GOBBI, K.F.; GARCIA, R.; VENTRELLA, M.C.; GARCEZ NETO, A.F.; ROCHA, G.C. Área foliar específica e anatomia foliar quantitativa do capim-braquiária e do amendoim-forrageiro submetidos a sombreamento. Revista Brasileira de Zootecnia, v.40, p.1436-1444, 2011.

GOMES, I.A.C.; CASTRO, E.M. de; SOARES, A.M.; ALVES, J.D.; ALVARENGA, M.I.N.; ALVES, E.; BARBOSA, J.P.R.A.D.; FRIES, D.D. Alterações morfofisiológicas em folhas de Coffea arabica L. cv. 'Oeiras' sob influência do sombreamento por Acacia mangium Willd. Ciência Rural, v.38, p.109-115, 2008. DOI: 10.1590/S0103-84782008000100018.

GONDIM, A.R. de O.; PUIATTI, M.; VENTRELLA, M.C.; CECON, P.R. Plasticidade anatômica da folha de taro cultivado sob diferentes condições se sombreamento. Bragantia, v.67, p.1037-1045, 2008.

JIANG, C.-D.; WANG, X.; GAO, H.-Y.; SHI, L.; CHOW, W.S. Systemic regulation of leaf anatomical structure, photosynthetic performance, and high-light tolerance in sorghum. Plant Physiology, v.155, p.1416-1424, 2011. DOI: 10.1104/pp.111.172213.

JOHANSEN, D.A. Plant microtechnique. New York: McGrawHill Book, 1940. 423p.

KIRCHNER, R.; SOARES, A.B.; SARTOR, L.R.; ADAMI, P.F.; MIGLIORINI, F.; FONSECA, L. Desempenho de forrageiras hibernais sob distintos níveis de luminosidade. Revista Brasileira de Zootecnia, v.39, p.2371-2379, 2010. DOI: 10.1590/ S1516-35982010001100009.

LOPES, C.M.; PACIULLO, D.S.C.; ARAÚJO, S.A.C.; GOMIDE, C.A.M.; MORENZ, M.J.F.; VILLELA, S.D.J. Massa de forragem, composição morfológica e valor nutritivo de capim-braquiária submetido a níveis de sombreamento e fertilização. Arquivo Brasileiro de Medicina Veterinária e Zootecnia, v.69, p.225233, 2017. DOI: $10.1590 / 1678-4162-9201$

MAJERAN, W.; VAN WIJK, K.J. Cell-type-specific differentiation of chloroplasts in $\mathrm{C} 4$ plants. Trends in Plant Science, v.14, p.100-109, 2009. DOI: 10.1016/j.tplants.2008.11.006.

MURPHY, M.R.C.; JORDAN, G.J.; BRODRIBB, T.J. Differential leaf expansion can enable hydraulic acclimation to sun and shade.

Pesq. agropec. bras., Brasília, v.53, n.12, p.1320-1328, Dec. 2018 DOI: 10.1590/S0100-204X2018001200004 
Plant, Cell \& Environment, v.35, p.1407-1418, 2012. DOI: 10.1111/j.1365-3040.2012.02498.x.

NIINEMETS, Ü.; SACK, L. Structural determinants of leaf lightharvesting capacity and photosynthetic potentials. In: ESSER, K.; LÜTTGE, U.; BEYSCHLAG, W.; MURATA, J. (Ed.). Progress in Botany: genetics, physiology, systematics, ecology. Berlin: Springer Verlag, 2006. v.67, p.385-419. DOI: 10.1007/3-54027998-9_17.

O'BRIEN, T.P.; FEDER, N.; MCCULLY, M.E. Polychromatic staining of plant cell walls by toluidine blue O. Protoplasma, v.59, p.368-373, 1964. DOI: 10.1007/BF01248568.

SANCHES, M.C.; MIELKE, M.S.; SOUZA, C.S.D. de; VIEIRA, A.J.D.; LOPES, M.M.M.; SILVA JÚNIOR, M.B. da. Morfologia foliar de indivíduos jovens e adultos de Caesalpinia echinata Lam. numa floresta semidecídua do sul da Bahia. Revista Árvore, v.33, p.885-893, 2009. DOI: 10.1590/S0100-67622009000500011.

SANTOS, M.V.; SILVA, D.V.; FONSECA, D.M. da; REIS, M.R. dos; FERREIRA, L.R.; OLIVEIRA NETO, S.N. de; OLIVEIRA, F.L.R. de. Componentes produtivos do milho sob diferentes manejos de plantas daninhas e arranjos de plantio em sistema agrossilvipastoril. Ciência Rural, v.45, p.1545-1550, 2015. DOI: 10.1590/0103-8478cr20141224.

SCHUMACHER, F.X.; HALL, F. dos S. Logarithmic expression of timber-tree volume. Journal of Agricultural Research, v.47, p.719-734, 1933.

TAIZ, L.; ZEIGER, E. Fisiologia vegetal. 5.ed. Porto Alegre Artmed, 2013. 918p

VALLADARES, F.; NIINEMETS, Ü. Shade tolerance, a key plant feature of complex nature and consequences. Annual Review of Ecology, Evolution and Systematics, v.39, p.237-257, 2008. DOI: 10.1146/annurev.ecolsys.39.110707.173506.

WELLES, J.M.; NORMAN, J.M. Instrument for indirect measurement of canopy architecture. Agronomy Journal, v.83, p.818-825, 1991. DOI: 10.2134/agronj1991.000219620083000500 $09 \mathrm{x}$.

WILKINSON, J.F.; BEARD, J.B. Anatomical responses of 'Merion' Kentucky bluegrass and 'Pennlawn' red fescue at reduced light intensities. Crop Science, v.15, p.189-194, 1975. DOI: 10.2135/cropsci1975.0011183X001500020014x.

Received on April 12, 2017 and accepted on February 27, 2018 